\title{
ВОССТАНОВЛЕНИЕ И АКТУАЛИЗАЦИЯ ОБЪЕКТОВ НАСЛЕДИЯ МАЛЫХ ИСТОРИЧЕСКИХ ГОРОДОВ БЕЛАРУСИ В 1990-Е - НАЧАЛЕ 2000-Х ГГ. (НА ПРИМЕРЕ РЕЗИДЕНЦИИ КНЯЗЕЙ РАДЗИВИЛЛОВ В Г. НЕСВИЖ)
}

\begin{abstract}
Анотація. У статті на основі архівних джерел з фондів Національного архіву Республіки Білорусь розкриваються процеси комплексного відновлення та актуалізації матеріальних нерухомих історико-культурних цінностей міста Несвіж, завдяки яким він став туристичним і культурним центром загальнодержавного масштабу, національним символом і одним з найбільш відвідуваних в Білорусі музейних комплексів. Цей процес, що почався в 1993 р. і тривав більше десяти років, увінчався включенням Несвіжського замку і всього палацово-паркового комплексу в Список всесвітньої спадщини ЮНЕСКО в 2005 р. Цей процес почався 3 вирішення майнових аспектів і об'єднання будівель і споруд на території міста Несвіжа, що представляють історико-культурну цінність, в один комплекс, на базі якого 2 липня 1993 р. було створено Національний історико-культурний музей-заповідник «Несвіж». У цей процес були залучені Рада Міністрів Білорусі в особі міністерств культури, економіки, освіти, охорони навколишнього середовища, оборони, підприємницької діяльності та інвестицій, охорони здоров'я, а також Державний комітет з економіки та планування, Несвіжський районний виконавчий комітет, Мінський обласний виконавчий комітет, Білоруський фонд культури, інститути Національної академії наук тощо. Основні зусилля в рамках проекту комплексного відновлення та актуалізації історико-культурної спадщини Несвіжа об'єднувалися з підготовкою святкування 770-річчя міста та 250-річчя несвіжського театру, щорічного Дня білоруського друку та писемності. Для цих цілей видавалися відповідні розпорядження президента Білорусі. Рада Міністрів також неодноразово приймала відповідні постанови і виділяла фінансування 3 коштів державного бюджету. Планувалося також надати палацово-парковому комплексу статус урядової резиденції Республіки Білорусь, але ця ідея реалізована, на жаль, не була. Роботи на об'єктах виконувалися відповідно до програми реставрації пам'яток, комплексної реконструкції будівель в межах історичних зон Несвіжа. Також міською владою проводилася естетизація міського середовища, було проведено коригування проекту регенерації історичної частини міста, розроблена концепція музеєфікації історичних будівель, також була підготовлена проектна документація для реставрації та нового використання будівель, що представляють історико-культурну цінність, тощо. Відновлення та актуалізація об'єктів спадщини міста під нові суспільні функції мало ефект синергії і дало імпульс для культурного та економічного розвитку всього міста.

Ключові слова: історико-культурна спадщина, реставрація, туризм, малі міста, Радзивілли, Несвіж, Білорусь, світова спадщина.
\end{abstract}

Постановка проблемы. К началу 1990-х гг. как в Беларуси, так и в Украине и в других постсоветских странах материальные недвижимые историко-культурные ценности зачастую находились в весьма плачевном состоянии. Неэффективная и избирательная советская политика охраны объектов наследия, приоритет сохранения идеологически и классово правильных памятников и комплексов вместе с планомерным уничтожением чуждых господствовавшей идеологии памятников, олицетворявших европейскость украинских и белорусских земель, дополнявшиеся масштабными социально-экономическими проблемами в СССР в 1980-е гг. привели к тому, что сфера наследия пребывала в состоянии глубокого кризиса. И лишь с обретением независимости наши страны получили возможность выстраивать самостоятельную политику в отношении собственного историко-культурного наследия, восстанавливать, реставрировать и актуализировать все памятники без оглядки на идеологию. Очевидно, что многое не удалось реализовать тогда (а зачастую и до настоящего времени) из-за нехватки средств, отсутствия комплексности в подходе к регенерации историко-культурных объектов и ландшафтов и других объективных факторов. Одномоментное восстановление и реставрация больших историко-культурных комплексов, таких как, например, исторические центры крупных городов, является практически невозможным даже сегодня из-за огромных финансовых средств, необходимых для этого. В то же время реализация такого рода проектов в относительно небольших населенных пунктах является вполне реальной задачей. Особенно в свете того, что именно в малых городах зачастую сохранилось множество недвижимых памятников истории и культуры. И те малые города, где государственные и местные органы власти сделали ставку в развитии населенного пункта именно на комплексное восстановление богатого историко-культурного наследия и придания ему новых социально значимых функций, демонстрируют весьма неплохие результаты. Одним из примеров такого комплексного восстановления и актуализации памятников наследия в Беларуси является город Несвиж, являвшийся на протяжении почти 500 лет главной резиденцией могущественного и богатейшего магнатского рода князей Радзивиллов. Благодаря предпринятым мерам Несвиж за относительно небольшой отрезок времени превратился в крупный центр культуры и туризма национального значения, стал настоящим символом независимой Беларуси и получил самое высокое международное признание. Поэтому изучение этого достаточно успешного опыта обладает очевидной актуальностью. 
Анализ последних исследований и публликаций показал, что проблема изучения исторического опыта восстановления объектов историко-культурного наследия и придания им новых социально значимых функций сегодня находит отклик в научных кругах. И интерес исследователей к этой теме лишь возрастает, растет заинтересованность изучением зарубежного опыта успешных проектов реставрации, ревитализации и актуализации объектов и комплексов историко-культурного наследия. В то же время основное внимание все же концентрируется на культурологических и музееведческих вопросах (Л.А. Гриффен [1], П.В. Дыренко [2], Т.А. Джумантаева [3]), вопросах развития туризма на основе ресурсов наследия (Л.М. Гайдукевич [4], И.Н. Власюк [5], В.А. Ганский [6], Н. Анипко [7]), экономических аспектах вовлечения в хозяйственный оборот объектов наследия (Д. Рипкема [8], В.А. Ганский [9], О.Н. Ильин [10], В.В. Козловский [11], И.И. Калачева [12]), правовых аспектах охраны материальных недвижимых историко-культурных ценностей (Мартыненко [13]) и др. При этом практически не изученным, за некоторыми исключениями (Е. Водзинский [14], С.3. Заремба [15]), остается собственно исторический аспект проблемы - относительно недавний опыт успешных управленческих практик в этой сфере периода конца XX и самого начала XXI вв. в контексте государственной политики и решений органов власти, который необходимо фиксировать, анализировать и распространять для целей возможного использования в других местах, регионах и странах.

Целью статьи является анализ процессов восстановления и актуализации недвижимых материальных историко-культурных ценностей малых исторических городов Беларуси в 1990-е - начале 2000-х гг. на примере одного из известнейших и самых успешных в Беларуси проектов такой деятельности - резиденции князей Радзивиллов в г. Несвиж Минской обл., включенной в Список всемирного наследия ЮНЕСКО.

Изложение основного материала исследования. В период с 1991 по начало 2000-х гг. на уровне центрального аппарата управления, региональных и местных ораганов власти Беларуси неоднократно поднимались вопросы восстановления и приспособления к новым функциям таких памятников истории и культуры, как объекты, связанные с жизнью и деятельностью выдающихся деятелей (художников, литераторов, политических фигур, монархов), городские ратуши, замки, дворцы, дворцово-парковые ансамбли, шляхетские усадьбы, памятники сакральной, гражданской и промышленной архитектуры и так далее. Систему взаимодействия заинтересованных министерств и ведомств, органов местного управления здесь можно проследить на примере регенерации и включения Несвижского дворцово-паркового ансамбля в культурное пространство города и страны.

Впервые на уровне центрального аппарата управления вопрос 0 возрождении резиденции князей Радзивиллов в г. Несвиж Минской обл. был рассмотрен в 1993 г. в связи с планированием празднования 770-летия г. Несвижа и 250-летия Несвижского театра. Постановлением Совета Министров Республики Беларусь между министерствами и ведомствами были распределены соответствующие полномочия и закреплены обязанности. В этой работе приняли участие министерства культуры, экономики, образования, охраны окружающей среды, обороны, предпринимательской деятельности и инвестиций, здравоохранения, а также Государственный комитет по экономике и планированию.
Совет Министров Республики Беларусь вместе с заинтересованными министерствами и ведомствами рассмотрел ходатайство о выделении финансовой помощи Несвижскому районному совету депутатов. С целью оптимизации и ускорения процесса проведения восстановительных работ и принимая во внимание выдающуюся ценность объекта, культурное достояние города Несвижа и его многовековую самобытную историю, было принято решение об открытии на базе дворцово-паркового ансамбля князей Радзивиллов историко-культурного заповедника. Таким образом, 2 июля 1993 г. был создан Национальный историко-культурный заповедник «Несвиж». А 22 мая 1997 г. он получил уже статус музея-заповедника. В 1993 г. планировалось предоставить дворцово-парковому комплексу также статус правительственной резиденции Республики Беларусь. Постановлением Совета Министров от 2 июля 1993 г. было поручено Министерству культуры и Управлению делами Совета Министров совместно с министерством иностранных дел в срок до 1 января 1994 г. разработать Положение о правительственной резиденции и внести его на рассмотрение Совета Министров. Однако практической реализации этих планов к сожалению так и не последовало [4, л. 50].

Министерство культуры и Минский областной исполнительный комитет подготовили программу работ по реставрации памятников, комплексной реконструкции зданий в пределах исторических зон Несвижа на 1995-2005 гг. Программа учитывала подготовку соответствующей инфраструктуры с целью позиционирования Несвижа как крупного туристического центра. Городскими властями проводились подготовительные работы по эстетизации городской среды, была проведена корректировка проекта регенерации исторической части города, разработана концепция музеефикации исторических зданий, подготовлена проектная документация для реставрации и нового использования здания городской ратуши. Однако из-за отсутствия финансирования в начале 1990-х гг. работы по реставрации практически не велись. Реализацию намеченных планов затрудняло и то обстоятельство, что объекты находились на балансе санатория «Несвиж» в структуре ОАО «Белагроздравница» (на тот момент еще «Белмежколхозздравница»). Однако еще в условиях функционирования на территории замка санаторного учреждения уже были начаты археологические и исследовательские работы. Управление «Белмежколхозздравницы» было обязано передать историко-культурные объекты замкового комплекса на баланс министерства культуры. В срок до 1997 г. санаторий должен был быть переведен на новую площадку. Кроме того, министерство обороны также имело на балансе ряд памятников архитектуры, такие как корпус монастыря бернардинцев на территории бывшего Несвежского коллегиума. Несвижский районный исполнительный комитет был обязан провести работы по прокладке инженерных сетей по исторической части города, дирекция же Несвижского историко-культурного музея-заповедника обязывалась разработать концепцию приспособления и использования дворцово-паркового ансамбля Радзивиллов (бывшего ранее санаторием) для новых социально-культурных функций. [17, л. 8].

С целью реставрации памятников Советом Министров было принято специальное постановление «0 мерах по использованию историко-культурного наследия и развитию г. Несвижа». Для формирования материальной базы заповедника ему была передана территория бывшего военного городка в центре 
города площадью 2,7 га. В состав городка входили двухэтажный учебный корпус, двухэтажный казарменный корпус, гаражи и др. Здания были отреставрированы, планировалось их использование под различные виды социально-культурной деятельности. Дирекция заповедника планировала создать там также центр ремесел: гончарства, столярства, кузнечества и др. Решением от 17 декабря 1993 г. Несвижский районный исполнительный комитет передал заповеднику заезжий двор - памятник архитектуры XIX в. [17, л. 266].

По случаю празднования 775-летия г. Несвижа распоряжением президента Республики Беларусь «Об утверждении плана основных мероприятий по эффективному использованию историко-культурного наследия Несвижа на 1997-2000 гг.» были определены в этой области основные задания и направления деятельности для соответствующих министерств и ведомств. План основных мероприятий по эффективному использованию историко-культурного наследия г. Несвижа на 1997-2000 гг. состоял из намеченных мероприятий, определенных сроков проведения и ответственных ведомств. Так, празднование 775-летия г. Несвижа было объединено с Днем белорусской печати и письменности в Несвиже в 1997 г. Ответственными были назначены министерство культуры, Минский областной исполнительный комитет и Несвижский районный исполнительный комитет. Дата проведения Дня белорусской печати и письменности была назначена на 7 сентября 1997 г. В состав рабочей группы были включены Государственный комитет по печати, Союз писателей и министерство культуры. Было запланировано подготовить и провести научно-практическую конференцию о роли г. Несвижа в исторической и культурной жизни Беларуси и Европы, ответственными за подготовку и проведение которой определялись Институт истории Национальной академии наук Беларуси и историко-культурный заповедник «Несвиж». Подготовить выставку по истории книгопечатания в Несвиже поручалось Государственному комитету по печати и Институту литературы Национальной академии наук Беларуси, Несвижскому районному исполнительному комитету поручалось организовать в дворцово-парковом ансамбле Радзивиллов музей, школу искусств, художественную выставку историко-культурного заповедника, провести экспедиционные работы по поиску историко-культурных ценностей в Несвижском, Слуцком, Кареличском, Столбцовском, Новогрудском, Щучинском районах, выявить и систематизировать исследовательские материалы по дворцово-парковому комплексу Радзивиллов (1997-2000 гг.). На Комитет по архивам и делопроизводству был возложен поиск и систематизация материалов по парку «Альба» (1997-2000 гг.). Белорусский фонд культуры и местный историко-культурный заповедник отвечали за формирование (восстановление) Несвижского архива князей Радзивиллов из материалов фондов исторических архивов Беларуси, Литвы, Польши, России и Украины (1997-2000 гг.) [18, л. 117].

Проектные и реставрационные работы в 1997-1998 гг. включали в себя завершение корректировки проекта регенерации исторической части г. Несвижа с разработкой охранных зон и зон регулирования застройки в историческом центре города, восстановления и реставрации отдельных памятников архитектуры, парков и инженерных коммуникаций. Отвечали за это министерство архитектуры и строительства институт «Белспецпроектреставрация» и министерство культуры. Завершение работ по корректуре генерального плана г. Несвижа производилось уже с учетом нового проекта регенерации и территориального развития. Этот процесс сопровождался соотвествующей информационной поддержкой через издательскую деятельность, которая была реализована через публикацию исследований белорусских и польских историков, искусствоведов, архитекторов и краеведов (1998 г.). Важным этапом здесь было формирование (восстановление) Радзивилловской библиотеки (1997-1998 гг.).

В рамках программы планировалось осуществить реставрационные работы здания плебании - памятника архитектуры XVI-XVIII в. (1997 г.), осуществить разработку проекта реставрации и приспособления памятников архитектуры в исторической части города под литературные и художественные музеи С. Будного, В. Сырокомли и Т. Маковского; организовать выставку архивных документов и инвентарей XVI-XVIII в., выполнить проектные и реставрационные работы торговых рядов XVIII в. с приспособлением этих объектов по их первиначальному назначению (1997-2000гг.), выполнить ремонтно-восстановительные работы городской ратуши, памятника архитектуры XVII в., с приспособлением под нужды историко-культурного заповедника (1997-1999 гг.), выполнить проектные и реставрационные работы одного из зданий историко-культурного заповедника с приспособлением под отель для туристов. Планировалось также возобновление деятельности мануфактур по изготовлению гобеленов, слуцких поясов, исторически стилизованной мебели, стекла, фаянса и так далее. Ответственными за исполнение этих задач были назначены министерство культуры и Союз художников Беларуси [17, л. 271].

В 2001 г. дворцово-парковый ансамбль князей Радзивиллов был передан на баланс Национальному историко-культурному музею-заповеднику «Несвиж». 15 июня 2005 г. архитектурный, жилой и культурный комплекс резиденции князей Радзивиллов был внесен в Список всемирного наследия ЮНЕСКО. В 1997-2004 гг. проходила реставрация городской ратуши. В результате ее фасад приобрел свой первоначальный вид, были восстановлены верхние ярусы башни с часами, в интерьерах второго этажа ратуши была открыта музейная экспозиция, посвященная истории городского самоуправления на белорусских землях, на первом этаже - детский образовательный центр и кафе. Реставрационные работы на Слуцких воротах города начались еще с 1970-х гг. и включали восстановление фасада и кровли, дубовых дверей, окон, лестницы на второй этаж, балкона на фасаде со стороны города. В сентябре 2007 г. завершился и этот процесс, территория вокруг памятника была благообустроена. Весь комплекс Слуцких ворот был открыт для посетителей в 2012 г.

Выводы. Таким образом, несмотря на сложные социальноэкономические и общественно-политические условия 1990-х и начала 2000-х гг, за чуть более чем десять лет г. Несвиж из достаточно заурядного постсоветского райцентра, благодаря восстановлению и актуализации его объектов историко-культурного наследия, находившихся во времена СССР в весьма плачевном состоянии, превратился в один из крупнейших в Беларуси центров культурно-познавательного туризма, практически до неузнаваемости изменив свой архитектурный облик, вернув былое величие и блеск европейского города - резиденции одного из богатейших магнатских родов Центральной и Восточной Европы - князей Радзивиллов, став национальным 
символом Беларуси, крупным музейным и исследовательским центром. Реставрация и перепрофилирование недвижимых объектов наследия под новые социально значимые функции имело эффект синергии и дало мощный импульс для развития всего города. Показателем эффективности проведенной работы стало высокое международное признание и включение Несвижского дворцово-паркового комплекса в 2005 г. в Список всемирного наследия ЮНЕСКО.

\section{Лumepamypa:}

1. Гриффен Л.А. Памятниковедение: основы теории и практики. Саарбрюккен: Palmarium Academic Publ., 2016. 265 c.

2. Диренко П.В. Фортифікаційні споруди Західної України: проблема збереження. Питання культурологіï. 2004. № 20. С. 31-39.

3. Джумантаева Т.А. Музеефікацыя культурнай прасторы Полацка: традыцыі і інавацыі: аўтарэф. дыс. ... канд. культуралогіi: 24.00.03. Мінск, 2011. 24 c

4. Гайдукевич Л.М. Культурно-историческое и природное наследие Беларуси: теория и практика использования в туризме. Минск : Четыре четверти, 2013. 345 с.

5. Власюк Н.Н. Культурно-туристский потенциал исторических усадеб. Вестник Брестского государственного технического университета. 2009. № 1. С. 3-6.

6. Ганський В.О. Комерціалізація ресурсів історико-культурної спадщини в туризмі: механізми, ліміти та бар'єри. Економіка та суспільство. 2018. Вип. 15. С. 95-99.

7. Аніпко Н. Середньовічні замки і фортеці. Рекреаційно-туристське використання. Краєзнавство. Географія. Туризм. 2011. № 20. C. 15-18.

8. Рипкема Д. Экономика исторического наследия. Москва : Билдинг Медиа Груп, 2006. 156 с

9. Ганський В.О. Історико-культурна спадщина як фактор локального соціально-економічного розвитку. Приазовський економічний вісник. 2018. № 2. С. 99-105.

10. Ильин О.Н. Инвестиции в сохранение объектов культурно-исторического наследия крупного города : автореф. дис... канд. экон. Наук : 08.00.05. Санкт-Петербург, 2009. 18 с.

11. Козловський В.В. Маркетинг історико-культурної спадщини та його специфіка в умовах комерціалізації сфери культури. Інфраструктура ринку. 2018. № 19. С. 39-44.

12. Калачова I.І. Стимулювання підприємництва і господарської діяльності у сфері історико-культурної спадщини. Причорноморські економічні студії. 2018. Вип. 32. С. 52-56.

13. Мартыненко И.Э. Правовая охрана историко-кульутрного наследия. Гродно : ГрГУ им. Я. Купалы, 2005. 251 с.

14. Водзинський $€$. Питання охорони своєрідності історичних міст України. Архітектурна спадщина України. 1995. № 2. С. 242-253.

15. Заремба С.З. Нариси 3 історії українського пам'яткознавства. Київ : Аратта, 2004. 204 с.

16. Национальный архив Республики Беларусь (НАРБ). Ф. 7. Оп. 12. Д. 1194.
17. НАРБ. Ф. 7. ОП. 16. Д. 4759.

18. НАРБ. Ф. 7. Оп. 12. Д. 2257.

Andreichyk K. Restoration and updating of heritage sites of small historical cities of Belarus in the 1990s and early 2000s (case of the Radziwill's residence at Nesvizh)

Summary. Based on archival sources from the National Archives of the Republic of Belarus, the article reveals the processes of complex restoration and updating of tangible immovable historical and cultural values of the city of Nesvizh, which made it a tourist and cultural center of national scale, a national symbol and one of the most visited museum complexes in Belarus. This process began in 1993 and it lasted for more than ten years, culminated in the inclusion of the Nesvizh castle and the entire palace and park complex in the UNESCO World Heritage List in 2005. This process began with solving the property aspects and combining buildings and structures on the territory of the city of Nesvizh, representing historical and cultural value, into one complex, on the basis of which the Nesvizh National Historical and Cultural Museum-Reserve was created on July 2, 1993. This process involved the Council of Ministers represented by the ministries of culture, economy, education, environment, defenses, business and investment, health and the State Committee for Economy and Planning, Nesvizh District Executive Committee, Minsk Regional Executive Committee, Belarusian Fund of Culture, the institutes of the National Academy of Sciences, etc. The main efforts under the project, a comprehensive restoration and updating of historical and cultural heritage of Nesvizh was merged with the preparation of the celebration of the 770 anniversary of the city and of the 250th anniversary of Nesvizh theatre, an Days of Belarusian Book Printing and Writing. For these purposes, the relevant orders of the President of Belarus were issued. The Council of Ministers has also repeatedly adopted relevant resolutions and allocated funding from the state budget. It was also planned to grant the palace and park complex the status of the government residence of the Republic of Belarus, but this idea was not implemented. Work on the sites was carried out in accordance with the program of restoration of monuments, complex reconstruction of buildings within the historical zones. Also, the city authorities carried out estheticization of the urban environment, adjusted the project of regeneration of the historical part of the city, developed the concept of museification of historical buildings, also prepared project documentation for the restoration and new use of buildings of historical and cultural value, and so on. The restoration and updating of the city's heritage sites for new public functions had a synergy effect and gave an impetus to the cultural and economic development of the entire city.

Key words: historical and cultural heritage, restoration, tourism, small towns, Radziwills, Nesvizh, Belarus, world heritage. 